Acta vet. scand. 1967, 8, 111-122.

From the Department of Animal Diseases, University of Connecticut, Storrs, USA.

\title{
MYCOPLASMA: NUTRITIONAL STUDIES OF LABORATORY STRAINS*)
}

By

H. Ern $\left.\phi^{\star \star}\right)$, W. N. Plastridge and M. E. Tourtellotte

Prior to a study on the occurrence of Mycoplasma in the prepuce and semen of bulls it was found necessary to compare growth of several laboratory strains on different mediums and under different atmospheric conditions to select a medium reasonably effective in growing all of the species or types involved.

\section{Nutrition and Growth Factors}

Proteinaceous and lipid growth factors. Characteristic of parasitic mycoplasmas is the requirement of serum or ascitic fluid for growth in vitro. A growth factor was separated (9) and identified as a lipoprotein (10) containing bound cholesterol and phospholipid, similar to, or a degeneration product of alpha-l lipoprotein found in mammalian sera. Mycoplasma hominis requires, in addition to the protein moiety of the lipoprotein, cholesterol and lecithin (10). As to the function of the abovementioned factors it was concluded that the lipoprotein might be involved in two functions, namely cellular permeability and oxidative phosphorylation (8). The levels of factors are of importance, being necessary to maintain a ratio of lecithin to cholesterol of 0.5 or less (10), with an optimum level of cholesterol constituting 0.01 to $0.02 \mathrm{mg} / \mathrm{ml}$.

*) Scientific contribution no. 265, Agricultural Experiment Station, University of Connecticut.

${ }^{\star}$ *) This investigation was supported, in part, by an International Fellowship from National Institutes of Health (FD5-TW-735) to the senior author, on leave of absence from the State Veterinary Serum Laboratory, Copenhagen, Denmark. 
Nucleic acid requirements. Edward \& Fitzgerald (4) in culturing mycoplasmas from the genital tract of cattle, noticed that colonies often appeared only in direct contact with vaginal mucus, and that some strains needed a growth factor also found in hog gastric mucin. Mucin could be replaced with calf thymus deoxyribonucleic acid (DNA). It was found (5) that 5 monophosphate nucleotides could replace peptone in a complex tissue culture medium supplemented with swine serum and peptone. A mixture of ribonucleosides and deoxyribonucleosides also supported good growth. A concentration of $0.5 \mathrm{mg} / 100 \mathrm{ml}$ of each nucleoside supported more growth than double this concentration.

Gaseous requirements. Mycoplasmas do not appear very exciting in their gaseous requirements. Most strains grow satisfactorily under aerobic conditions, but some require anaerobic or microaerophilic conditions, or an atmosphere of air plus $10 \%$ $\mathrm{CO}_{2}$, while some are inhibited by $10 \% \mathrm{CO}_{2}(3)$. It was found that anaerobic growth of Mycoplasma gallisepticum could be obtained only if pyruvate was added as a hydrogen recipient (6).

Mediums. The most widely used basal mediums are those containing either fresh or dehydrated beef heart infusion with the addition of $1 \%$ peptone. Ascitic fluid, different mammalian serums, serum fractions, blood, egg yolk, yeast extracts, hog gastric mucin, nucleic acids, and filtered staphylococcus broth culture are most commonly used for enrichment. A commercial product in general use is Bacto PPLO serum fraction, which is a partially purified bovine serum fraction.

\section{MATERIALS AND METHODS}

Cultures. A total of 12 strains were used and were maintained by weekly subinoculations of $0.5 \mathrm{ml}$ of culture into $8.0 \mathrm{ml}$ of Bacto brain heart infusion broth plus Bacto PPLO serum fraction $(1.0 \%)$. Generally only 4 strains were used per experiment. The source of strains is given in Table 1.

Inoculum. Cultures, 48-hour-old, were diluted up to $10^{-5}$ in $2.9 \%$ sodium citrate and the inoculation was done with a loop designed to transfer $0.01 \mathrm{ml}$ of liquid.

Determination of growth. In experiments with solid mediums examination of plates was done after $2,3,4,5,6$, and 7 days and growth recorded and coded as shown in Table 2.

The evaluation of growth was based solely on the appearance of visible colonies, that is colony size and morphology were not taken into consideration. In broth, growth was determined by a light transmission technique using a Beckman, Model B, Spectrophotometer, 
T a b l e 1. Source of strains.

\begin{tabular}{lll}
\hline Strain & Animal & Organ or disease \\
\hline Donetta & cattle & mastitis \\
Palmer & cattle & mastitis \\
Curtiss & cattle & mastitis \\
Wells & cattle & mastitis \\
A60549 & cattle & vagina \\
C79 & cattle & respiratory tract \\
155 & cattle & respiratory tract \\
A5969 & chicken & CRD \\
Kid & goat & $?$ \\
H39 & man & genital tract \\
Ovine 3 & sheep & lung \\
M. laidlawii A & "sewage" & - \\
\hline
\end{tabular}

T a b l e 2. Evaluation of growth on agar medium.

\begin{tabular}{cccc}
\hline & \multicolumn{4}{c}{ Values for growth: } \\
\cline { 2 - 4 } $\begin{array}{c}\text { Dilution } \\
\text { of } \\
\text { inoculum }\end{array}$ & \multicolumn{4}{c}{ Days before appearance of visible colonies } \\
& 2 & 3 to 4 & 5 to 7 \\
\hline $10^{-2}$ & 3 & 2 & 1 \\
$10^{-3}$ & 4 & 3 & 2 \\
$10^{-4}$ & 5 & 4 & 3 \\
$10^{-5}$ & 6 & 5 & 4 \\
\hline
\end{tabular}

48-hour-old cultures in brain heart infusion broth plus $1.0 \%$ Bacto PPLO serum fraction. Inoculum: $0.01 \mathrm{ml}$ of each dilution.

wave length $550 \mathrm{~m} \mu$. The growth was expressed as per cent of light absorption when compared with uninoculated broth.

Effect of source of blood on growth of mycoplasmas on beef extract agar and beef infusion agar plus PPLO serum fraction $(1.0 \%)$ was determined. To each of these mediums were added $5 \%$ of defibrinated ox blood, sheep blood, or horse blood. Inoculations were done with $10^{-2}, 10^{-3}$, and $10^{-4}$ dilutions of 48-hour-old cultures. Incubation was at $37^{\circ} \mathrm{C}$ in an atmosphere of $5 \% \mathrm{O}_{2}, 10 \% \mathrm{CO}_{2}$, and $85 \% \mathrm{~N}_{2}$.

Effect of yeast extract on growth of mycoplasmas on beef infusion agar with horse blood, and on Bacto PPLO agar with horse blood and PPLO serum fraction was determined. Two yeast extracts were used, Bacto yeast extract $(1 \%)$ and a freshly prepared yeast extract $(5 \%)$. The fresh yeast extract was prepared by suspending $25 \mathrm{~g}$ of fresh yeast (Fleischmán) in $100 \mathrm{ml}$ distilled water, boiling for $2 \mathrm{~min}$., centrifuging, and sterilizing the supernatant fluid by filtration. Bacto 
yeast extract was added before autoclaving, and fresh yeast extract added after autoclaving. Inoculations were done with $10^{-2}, 10^{-3}$, and $10^{-4}$ dilutions of culture. Incubation was at $37^{\circ} \mathrm{C}$ in an atmosphere of $90 \%$ air plus $10 \% \mathrm{CO}_{2}$ for all cultures with the exception of Mycoplasma laidlawii $\mathrm{A}$, which was incubated aerobically.

Effect of mucin on growth of mycoplasmas on Bacto PPLO agar with $5 \%$ horse blood and $1 \%$ PPLO serum fraction was determined. One \% of gastric mucin (lyophilized gastric mucosa-pork $\left.{ }^{*}\right)$ ) was added to the basal medium. Inoculations were done with $10^{-2}, 10^{-3}$, and $10^{-4}$ dilutions of cultures, and 2 plates of each medium were inoculated; one as usual and the other with 1 loopful of a $2 \%$ suspension of gastric mucin combined with the inoculum. Incubation was at $37^{\circ} \mathrm{C}$ in an atmosphere of $90 \%$ air and $10 \% \mathrm{CO}_{2}$ for all cultures with the exception of M. laidlawii $A$ and $A 60549$ which were incubated aerobically.

Effect of yeast hydrolysate, swine serum, and nucleosides. Three different mediums were used: (1) Bacto PPLO agar with PPLO serum fraction $(1 \%)$ and yeast hydrolysate $\left.{ }^{*}\right)(1 \%)$; (2) As above but $10 \%$ unheated swine serum was added after autoclaving; and (3) Difco PPLO agar with PPLO serum fraction (1\%) supplemented with $0.05 \%$ of adenosine, cytidine, guanosine, deoxyadenosine, deoxycytidine, deoxyguanosine, thymidine, and uridine. The nucleosides ${ }^{\star}$ ) were dissolved in water and the solution was sterilized by Gelman filtration (pore size $0.45 \mu$ ). All mediums contained thallium acetate $(0.005 \%)$ and penicillin $\mathrm{G}(100 \mathrm{i} . \mathrm{u} . / \mathrm{ml})$. Inoculations were done with culture dilutions of $10^{-2}, 10^{-3}$, and $10^{-4}$.

Four different mediums were used to determine the effect of yeast hydrolysate, swine serum, and extract of pig's stomach: (1) Bacto PPLO agar, Difco PPLO serum fraction (1\%), and yeast hydrolysate (1\%); (2) Bacto PPLO agar and extract of pig's stomach (1:1); (3) Bacto PPLO agar, extract of pig's stomach (1:1); and Difco PPLO serum fraction (1\%); and (4) Bacto PPLO agar, extract of pig's stomach $(1: 1)$, and swine serum $(10 \%)$.

The extract of pig's stomach was prepared by the method of Barber \& Fabricant (2). Inoculations were done with dilutions of $10^{-2}, 10^{-3}, 10^{-4}$, and $10^{-5}$ of 48 -hour-old cultures in Bacto brain heart infusion broth. Four strains were used; M. laidlawii A and A60549 were incubated aerobically, Donetta and C79 were incubated in an atmosphere of $90 \%$ air and $10 \% \mathrm{CO}_{2}$.

Twelve strains were used to determine the effect of atmosphere on growth of mycoplasmas on Bacto PPLO agar with $5 \%$ horse blood, $1 \%$ PPLO serum fraction and $0.005 \%$ of 8 nucleosides. Inoculations were done with dilutions of $10^{-2}, 10^{-3}, 10^{-4}$, and $10^{-5}$ of a 48-hour-old culture of each strain, and the plates were incubated under 6 different atmospheric conditions: (1) $85 \% \mathrm{~N}_{2}, 5 \% \mathrm{O}_{2}$, and $10 \% \mathrm{CO}_{2}$; (2) $80 \%$ Ohio.

*) Nutritional Biochemicals Corporation, (N.B.C.) Cleveland 28, 
$\mathrm{N}_{2}, 10 \% \mathrm{O}_{2}$, and $10 \% \mathrm{CO}_{2}$; (3) $72 \% \mathrm{~N}_{2}, 18 \% \mathrm{O}_{2}$, and $10 \% \mathrm{CO}_{2}$; (4) $90 \% \mathrm{~N}_{2}$ and $10 \% \mathrm{CO}_{2}$; (5) $100 \% \mathrm{~N}_{2}$; and (6) air.

Effect of adding PPLO serum fraction, swine serum, nucleosides, and yeast extract to bacto brain heart infusion broth. Tubes containing $10 \mathrm{ml}$ of brain heart infusion broth alone or supplemented with the previously mentioned enrichments were inoculated with $0.1 \mathrm{ml}$ of 48-hour-old cultures; the turbidity was measured with a spectrophotometer.

\section{RESULTS}

\section{Effect of source of blood}

Horse blood gave better results than cow blood or sheep blood. Both beef extract agar and beef infusion agar with $1 \%$ PPLO serum fraction, when supplemented with horse blood, supported growth of 3 of the 4 strains used (Table 3 ).

Table 3. Effect of source of blood on growth of Mycoplasma on beef extract and beef infusion agar.

\begin{tabular}{|c|c|c|c|c|c|c|}
\hline \multirow{3}{*}{ Strain } & \multicolumn{6}{|c|}{ Values for growth with: } \\
\hline & \multicolumn{3}{|c|}{$\begin{array}{l}\text { Beef extract agar }+ \\
\text { blood }(5 \%) \text { from }\end{array}$} & \multicolumn{3}{|c|}{$\begin{array}{l}\text { Beef infusion agar } \\
\text { with S.F. }(1 \%)+ \\
\text { blood }(5 \%) \text { from }\end{array}$} \\
\hline & Cow & Sheep & Horse & Cow & Sheep & Horse \\
\hline Donetta & 3 & 4 & 4 & 0 & 0 & 4 \\
\hline Palmer & 3 & 2 & 4 & 3 & 2 & 4 \\
\hline A60549 & 0 & 0 & $\mathbf{0}$ & $\mathbf{0}$ & $\mathbf{0}$ & 0 \\
\hline M. laidlawii A & 4 & 4 & 4 & 4 & 4 & 4 \\
\hline
\end{tabular}

Beef extract agar: Beef extract (Difco), $0.3 \%$; proteose peptone (Difco), $1.0 \%$; NaCl, $0.5 \%$; Bacto agar, $2.0 \%$; $\mathrm{pH}$ 7.4.

Beef infusion agar: Fresh beef heart infusion plus proteose peptone (Difco), $1.0 \%$; NaCl, $0.5 \%$; Bacto agar, $2.0 \%$; $\mathrm{pH}$ 7.4.

S. F.: Bacto PPLO serum fraction.

Inoculum: $0.01 \mathrm{ml}$ of dilutions of $10^{-2}, 10^{-3}$, and $10^{-4}$ of 48 -hourold cultures in brain heart infusion broth plus PPLO serum fraction (Difco).

Atmosphere: $5 \% \mathrm{O}_{2}, 10 \% \mathrm{CO}_{2}, 85 \% \mathrm{~N}_{2}$.

Note: Poor growth of strain A60549 may have been due to the particular atmosphere used. See Table 6.

\section{Effect of yeast extract}

When beef infusion agar with $5 \%$ horse blood was used as a base, the addition of yeast extract and fresh yeast extract improved the growth of strain A60549, whereas a negative effect 
was seen when the base was Bacto PPLO agar with $5 \%$ horse blood and $1 \%$ PPLO serum fraction. Fresh beef heart infusion horse blood agar alone was inferior to Bacto PPLO horse blood agar. However, when fresh yeast extract was added, growth equalled that obtained in the PPLO agar medium. The experiment does not support the desirability of adding yeast extract, when Bacto PPLO agar with horse blood (5\%) and PPLO serum fraction $(1 \%)$ is the basic medium (Table 4 ).

T a b l e 4. Effect of yeast extract on growth of Mycoplasma.

\begin{tabular}{|c|c|c|c|c|c|c|}
\hline \multirow{4}{*}{ Strain } & \multicolumn{6}{|c|}{ Values for growth with: } \\
\hline & \multirow{2}{*}{\multicolumn{3}{|c|}{$\begin{array}{l}\text { Beef infusion agar with } \\
\text { horse blood }(5 \%) \\
\text { supplemented with } \\
\text { Yeast extract }\end{array}$}} & \multirow{2}{*}{\multicolumn{3}{|c|}{$\begin{array}{c}\text { Bacto PPLO agar with } \\
\text { horse blood }(5 \%) \text { and } \\
\text { PPLO serum fraction }(1.0 \%) \\
\text { supplemented with } \\
\text { Yeast extract }\end{array}$}} \\
\hline & & & & & & \\
\hline & None & $\begin{array}{l}\text { Bacto } \\
(1 \%)\end{array}$ & $\begin{array}{l}\text { Fresh }^{\star} \\
(5 \%)\end{array}$ & None & $\begin{array}{l}\text { Bacto } \\
(1 \%)\end{array}$ & $\begin{array}{l}\text { Fresh }^{\star} \\
(5 \%)\end{array}$ \\
\hline Donetta & 4 & 4 & 5 & 5 & 5 & 5 \\
\hline Palmer & 5 & 4 & 5 & 5 & 3 & 4 \\
\hline A60549 & 0 & 3 & 2 & 1 & 0 & 0 \\
\hline C79 & 5 & 5 & 5 & 5 & 5 & 5 \\
\hline H39 & 4 & $\mathbf{0}$ & 3 & 5 & 5 & 5 \\
\hline M. laidlawii A & 5 & 5 & 5 & 5 & 0 & 5 \\
\hline
\end{tabular}

* Fresh yeast extract: To $100 \mathrm{ml}$ of medium were added $5 \mathrm{ml}$ of an extract prepared by suspending $25 \mathrm{~g}$ of fresh yeast (Fleishman's) in $100 \mathrm{ml}$ of distilled water. The mixture was boiled for $2 \mathrm{~min}$., centrifuged, and the supernatant fluid sterilized by filtration.

Inoculum: $0.01 \mathrm{ml}$ of dilutions of $10^{-2}, 10^{-3}$, and $10^{-4}$ of 48 -hourold cultures in brain heart infusion broth with $1 \%$ PPLO serum fraction.

Atmosphere: Air, $90 \%, \mathrm{CO}_{2}, 10 \%$; except M. laidlawii A which was incubated aerobically.

Note: Poor growth of strain A60549 may have been due to the atmosphere used. See Table 6 .

\section{Effect of mucin}

When the basic medium was Bacto PPLO agar with $5 \%$ horse blood and $1 \%$ PPLO serum fraction, the addition of mucin had a slightly negative effect when mucin was incorporated in the medium (Table 5). 
T a ble 5. Summary of effect of additives to Bacto PPLO horse blood agar.

\begin{tabular}{|c|c|c|c|c|c|c|c|c|c|c|c|}
\hline \multirow{5}{*}{ Strain } & \multicolumn{11}{|c|}{ Values*) for growth with: } \\
\hline & \multicolumn{11}{|c|}{ Bacto PPLO horse blood agar plus } \\
\hline & \multicolumn{9}{|c|}{ PPLO serum fraction $1 \%$} & \multirow{3}{*}{$\left|\begin{array}{c}\text { Extract } \\
\text { of pig's } \\
\text { stomach }\end{array}\right|$} & \multirow[b]{3}{*}{$\begin{array}{l}\text { Swine } \\
\text { serum }\end{array}$} \\
\hline & & $\begin{array}{l}\text { Nucleo- } \\
\text { sides }\end{array}$ & \multicolumn{2}{|c|}{ Yeast hydrol. } & \multicolumn{2}{|c|}{ Yeast extract } & \multicolumn{2}{|c|}{ Mucin } & \multirow[t]{2}{*}{$\begin{array}{l}\text { Extract } \\
\text { of pig's } \\
\text { stomach }\end{array}$} & & \\
\hline & & & & $\begin{array}{l}\text { Swine } \\
\text { serum }\end{array}$ & Bacto & Fresh & & $\left|\begin{array}{c}1 \text { loopful } \\
\text { of gastric } \\
\text { mucin }\end{array}\right|$ & & & \\
\hline Donetta & 5 & 6 & 4 & 4 & 5 & 5 & 4 & 3 & 6 & 5 & 6 \\
\hline C79 & 6 & 6 & 6 & 6 & 5 & 5 & 4 & 4 & 6 & 6 & 6 \\
\hline A60549 & 4 & 6 & 2 & 2 & $\mathbf{0}$ & $\mathbf{0}$ & 4 & 4 & 5 & 5 & $\mathbf{0}$ \\
\hline M. laid. & 5 & 6 & 3 & 6 & $\mathbf{0}$ & 5 & - & - & 3 & 4 & 4 \\
\hline Palmer & 5 & 6 & - & - & 3 & 4 & 4 & 3 & - & - & - \\
\hline H39 & $\mathbf{5}$ & 5 & - & - & 5 & 5 & - & - & - & - & - \\
\hline
\end{tabular}

*) Values: Maximum 6, minimum 0 (Table 2).

Effect of yeast hydrolysate, swine serum, and nucleosides

The addition of nucleosides $(0.005 \%$ of adenosine, cytidine, guanosine, deoxyadenosine, deoxycytidine, deoxyguanosine, thymidine, and uridine) to the basic medium produced better growth of 3 of 4 strains than did addition of yeast hydrolysate $(1.0 \%)$ alone or further supplemented with swine serum (10\%) (Table 5 ).

Effect of yeast hydrolysate, swine serum, and extract of pig's stomach

Using Bacto PPLO agar with $5 \%$ horse blood as the basic medium, extract of pig's stomach (prepared by the method of Barber \& Fabricant (2)) was a better supplement than yeast hydrolysate plus PPLO serum fraction. Addition of PPLO serum fraction to pig-stomach medium did not improve growth, whereas addition of swine serum $(10 \%)$ prevented growth of strain A60549 (Table 5).

\section{Effect of atmosphere}

Eight of 12 strains grew equally well under all 6 different atmospheric conditions. One strain (Donetta) seemed to prefer 
Table 6. Effect of atmosphere on growth of mycoplasmas.

\begin{tabular}{|c|c|c|c|c|c|c|}
\hline \multicolumn{7}{|c|}{ Values for growth in: } \\
\hline Strain & $\begin{array}{ccc}5 \% & \mathrm{O}_{2} \\
85 \% & \mathrm{~N}_{2} \\
10 \% & \mathrm{CO}_{2}\end{array}$ & $\begin{array}{l}10 \% \mathrm{O}_{2} \\
80 \% \mathrm{~N}_{2} \\
10 \% \mathrm{CO}_{2}\end{array}$ & $\begin{array}{l}18 \% \mathrm{O}_{2} \\
72 \% \mathrm{~N}_{2} \\
10 \% \mathrm{CO}_{2}\end{array}$ & $\begin{array}{l}90 \% \mathrm{~N}_{2} \\
10 \% \mathrm{CO}_{2}\end{array}$ & $100 \% \mathrm{~N}_{2}$ & Air \\
\hline Donetta & 6 & 6 & 6 & 6 & 4 & 5 \\
\hline Palmer & 5 & 5 & 6 & 6 & 6 & 6 \\
\hline Curtiss & 6 & 6 & 6 & 6 & 6 & 6 \\
\hline Wells & 6 & 6 & 6 & 6 & 6 & 6 \\
\hline A60549 & $\mathbf{0}$ & 0 & 0 & 3 & 4 & 5 \\
\hline C79 & 6 & 6 & 6 & 6 & 6 & 6 \\
\hline 155 & 5 & 6 & 6 & 5 & 4 & 4 \\
\hline A5969 & 0 & 0 & 2 & 4 & 3 & 5 \\
\hline Kid & 5 & 3 & 3 & 3 & 3 & 5 \\
\hline H39 & 5 & 5 & 5 & 5 & 5 & 5 \\
\hline Ovine 3 & 6 & 5 & 5 & 6 & 6 & 6 \\
\hline M. laidlawii A & 0 & 0 & 2 & 4 & 6 & 6 \\
\hline
\end{tabular}

Medium: Bacto PPLO agar containing horse blood, 5.0\%; PPLO serum fraction, $1.0 \% ; 8$ nucleosides; thallium acetate, $0.05 \%$; and penicillin G, 100 i.u. $/ \mathrm{ml}$.

Inoculum: $0.01 \mathrm{ml}$ of dilutions of $10^{-2}, 10^{-3}, 10^{-4}$, and $10^{-5}$ of 48-hour-old cultures in brain heart infusion broth with $1 \%$ PPLO serum fraction.

an atmosphere with added $\mathrm{CO}_{2}$, while this gas had a negative effect on M. laidlawii A and strains A60549 and A5969 (Table 6).

Effect of adding PPLO serum fraction, swine serum, nucleosides and yeast extract to brain heart infusion broth

The Donetta and C79 strains needed either PPLO serum fraction or swine serum for growth in brain heart infusion broth, however, growth was reduced when yeast extract was added together with PPLO serum fraction. The best medium for these 2 strains was the base supplemented with PPLO serum fraction, nucleosides, and swine serum. Strain A60549 grew in brain heart infusion broth alone, but did not grow in any of the mediums containing swine serum. M. laidlawii A was also able to grow in unenriched broth, but growth was improved by the addition of PPLO serum fraction, nucleosides or swine serum. All strains grew in brain heart infusion broth plus PPLO serum fraction (Table 7). 
Table 7. Effect of adding PPLO serum fraction, swine serum, nucleosides, and yeast extract to brain heart infusion broth on growth of Mycoplasma* ${ }^{\star}$.

\begin{tabular}{|c|c|c|c|c|c|c|c|c|c|}
\hline \multirow[b]{3}{*}{ Strain } & \multicolumn{6}{|c|}{ Bacto brain heart infusion broth } & \multicolumn{3}{|c|}{ supplemented with: } \\
\hline & & \multirow[b]{2}{*}{ 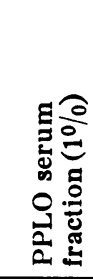 } & \multirow[b]{2}{*}{ 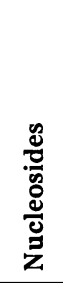 } & \multirow[b]{2}{*}{ 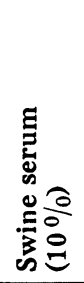 } & \multicolumn{2}{|c|}{$\begin{array}{l}\text { Nucleosides } \\
\text { and }\end{array}$} & \multicolumn{3}{|c|}{$\begin{array}{l}\text { PPLO serum fraction } \\
(1 \%) \text { and }\end{array}$} \\
\hline & $\begin{array}{l}\text { 巳 } \\
\text { z }\end{array}$ & & & & 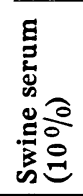 & 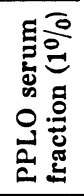 & 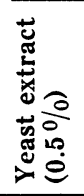 & 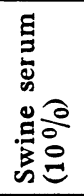 & 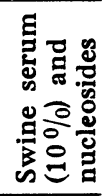 \\
\hline Donetta & 0 & 15 & 0 & 8 & 11 & 12 & 6 & 10 & 18 \\
\hline $\mathrm{A} 60549$ & 17 & 39 & 19 & 0 & $\mathbf{0}$ & 41 & 37 & 0 & 0 \\
\hline C79 & 0 & 13 & 3 & 8 & 10 & 9 & 5 & 11 & 34 \\
\hline M. laidlawii A & 31 & 52 & 38 & 40 & 31 & 58 & 45 & 42 & 40 \\
\hline
\end{tabular}

*) Growth expressed as per cent of light absorption when compared with uninoculated broth, as determined at a wave length of $550 \mathrm{~m} \mu$ with a Beckman, Model B, Spectrophotometer.

Nucleosides: $0.005 \%$ of adenosine, cytidine, deoxyadenosine, deoxycytidine, deoxyguanosine, guanosine, thymidine, and uridine.

Yeast extract: Difco.

Inoculum: $0.1 \mathrm{ml}$ of 48 -hour-old cultures in brain heart infusion broth with $1 \%$ PPLO serum fraction.

Note: Broth cultures recorded as " $O$ " failed to yield colonies when subcultured on (1) PPLO horse blood agar plus serum fraction and nucleosides, and (2) the same medium plus swine serum.

\section{DISCUSSION AND CONCLUSIONS}

Bacto PPLO agar supplemented with PPLO serum fraction (1\%) and horse blood ( $5 \%$ ) supported growth of 12 laboratory strains of mycoplasmas isolated from different sources.

It was found that Bacto PPLO agar was as satisfactory as fresh beef infusion agar, and that horse blood was superior to cow blood and sheep blood.

The addition of yeast extracts and mucin to Bacto PPLO agar plus serum fraction did not result in increased growth (Table 5). However, the addition of fresh yeast extract to fresh beef infusion agar, as done by Albertsen (1), increased growth of some strains (Table 4). This author also found that the addition of mucus did not improve growth. Also of interest is the negative effect of swine serum on growth of certain strains. The positive effect of nucleosides on growth is in agreement with the work of Fabricant 
et al. (5); whether the effect is caused by a detoxifying factor or a true growth promoting factor is not known. As noted by several authors, it is difficult to compare results of different workers, because of differences in basic mediums used and the probable critical balance between growth promoting and inhibitory factors in these mediums.

Barber \& Fabricant (2) concluded that it is necessary to use a variety of mediums. It seems that one could also be justified in concluding, from their results, that the addition of yeast hydrolysate to mediums used for primary isolation of mycoplasmas is of great importance.

Regarding atmospheric conditions, it seems, according to the literature, that some mycoplasmas from the human genitourinary tract require "anaerobic" conditions for growth. Also it is generally agreed that some strains, especially $M$. mycoides, are inhibited by $\mathrm{CO}_{2}$, however, Rodwell \& Rodwell (7) obtained the best growth with this organism in an atmosphere of $95 \% \mathrm{O}_{2}$ and $5 \% \mathrm{CO}_{2}$ when a liquid medium was used. Tourtellotte (11) used, among other strains, M. laidlawii A, M. gallisepticum (A5969) and found that they grew best in a liquid medium in an atmosphere containing 1 to $5 \% \mathrm{O}_{2}$ and $10 \% \mathrm{CO}_{2}$. As reported herein, these 2 strains grew best in air when a solid medium was used. These differences tend to illustrate the effect of the type of medium used on gaseous requirements for growth. Differences in chemical composition of the medium can also induce divergent results as pointed out by Gill (6), who found that anaerobic growth of the avian strain A5969 could be obtained only when pyruvate was added to the medium.

\section{REFERENCES}

1. Albertsen, B. E.: Pleuropneumonia-like organisms in the semen of Danish artificial insemination bulls. Nord. Vet.-Med. 1955, 7, 169-200.

2. Barber, T. L. \& J. Fabricant: Primary isolation of Mycoplasma organisms (PPLO) from mammalian sources. J. Bact. 1962, $83,1268-1273$.

3. Edward, D. G. ff.: The pleuropneumonia group of organisms: A review together with some new observations. J. gen. Microbiol. 1954, 10, 27-64.

4. Edward, D. G. ff. \& W. A. Fitzgerald: A growth factor needed to isolate organisms of the pleuropneumonia group from the genital tract of cattle. Vet. Rec. 1952, 64, 395-396. 
5. Fabricant, C. E., J. Fabricant \& P. J. Van Demark: Studies on the nutrition and growth requirements of Mycoplasma gallisepticum. J. gen. Microbiol. 1964, 35, 135-144.

6. Gill, F. W.: Culture and metabolism of Mycoplasma gallisepticum. J. Bact. 1963, 83, 213-218.

7. Rodwell, A. W. \& E. S. Rodwell: The breakdown of carbohydrates by Asterococcus mycoides, the organism of bovine pleuropneumonia. Aust. J. biol. Sci. 1954, 7, $18-30$.

8. Smith, P. F.: Nutritional requirements of PPLO and their relation to metabolic function. Ann. N. Y. Acad. Sci. 1960, 79, 508520.

9. Smith, P. F. \& H. E. Morton: The separation and characterization of the growth factor in serum and ascitic fluid which is required by certain pleuropneumonia-like organisms. J. Bact. 1951, 61, 395-405.

10. Smith, P. F., J. G. Lecce \& R. F. Lynn: A lipoprotein as a growth factor for certain pleuropneumonia-like organisms. J. Bact. $1954,68,627-633$.

11. Tourtellotte, M. E.: A Comparative Serologic and Physiologic Study of Pleuropneumonia-like Organisms. Thesis. University of Connecticut 1960.

\section{SUMMARY}

Growth of 12 laboratory strains of Mycoplasma isolated from cattle, chicken, goat, man and sewage were studied on 20 different solid mediums and 9 liquid mediums. Growth on solid mediums was evaluated on the basis of appearance of visible colonies, while growth in liquid mediums was determined by light transmission technique. A solid medium of Bacto PPLO agar + Bacto PPLO serum fraction $(1 \%)+$ horse blood $(5 \%)$, and $0.005 \%$ of 8 nucleosides (adenosine, cytidine, guanosine, deoxyadenosine, deoxycytidine, deoxyguanosine, thymidine, and uridine) was unsurpassed by any other medium. Studies of atmospheric requirements demonstrated that all strains grew in jars containing either air or nitrogen $(100 \%)$. One strain preferred an atmosphere with $10 \% \mathrm{CO}_{2}$, while 3 strains were inhibited by this concentration of carbon dioxide.

\section{ZUSAMMENFASSUNG}

Mykoplasma: Nährbödenuntersuchungen von Laboratoriestämmen.

Das Wachstum von 12 Iaboratoriestämmen von Mykoplasmen von Mensch, verschiedenen Tierarten (Vieh, Geflügel, Ziege) und Abwasser wurde an 20 festen und 9 flüssigen Substraten untersucht. Auf den Nährböden wurde das Wachstum auf Grundlage von dem Erscheinen und der Anzahl der Kolonien beurteilt, während das Wachstum in 
Bouillonen mit Hilfe von Phototransmissionen bestimmt wurde. Ein Medium bestehend aus Bacto PPLO Agar mit Bacto PPLO Serum Fraktion $(1 \%)$, Pferdeblut $(5 \%)$ und $0,005 \%$ von 8 Nukleosiden (Adenosin, Cytidin, Guanosin, Deoxyadenosin, Deoxycytidin, Deoxyguanosin, Thymidin und Uridin) war zu bevorzugen.

Alle Stämme zeigten Wachstum sowohl aerob wie anaerob. Ein Stamm bevorzugte eine Atmosphäre mit $10 \% \quad \mathrm{CO}_{2}$, während das Wachstum von 3 Stämmen unter diesen Bedingungen reduziert wurde.

\section{SAMMENDRAG}

Mykoplasma: Unders $\phi g e l s e$ af forskellige mediers indflydelse på væksten af laboratoriestammer.

Væksten af 12 laboratoriestammer af mykoplasmer fra menneske, forskellige dyrearter (kvæg, fjerkræ, ged) og spildevand unders $\varnothing$ gtes på 20 faste og 9 flydende substrater. På pladerne vurderedes væksten på grundlag af tilsynekomst og antal af kolonier, medens væksten i bouilloner bestemtes ved fototransmission. Et medium bestående af Bacto PPLO agar med Bacto PPLO serum fraktion (1\%), hesteblod $(5 \%)$ og $0,005 \%$ af 8 nukleosider, adenosin, cytidin, guanosin, deoxyadenosin, deoxycytidin, deoxyguanosin, thymidin og uridin) var at foretrække.

Alle stammer viste vækst både aerobt og anaerobt. Een stamme foretrak en atmosphære med $10 \% \mathrm{CO}_{2}$, medens væksten af 3 stammer reduceredes under disse betingelser.

(Received October 28, 1966). 